\title{
Extracellular Vesicles, Tunneling Nanotubes, and Cellular Interplay: Synergies and Missing Links
}

\author{
Muhammad Nawaz ${ }^{1,2 *}$ and Farah Fatima ${ }^{1}$ \\ 1 Department of Pathology and Forensic Medicine, Ribeirao Preto Medical School, University of São Paulo, São Paulo, Brazil, \\ ${ }^{2}$ Department of Rheumatology and Inflammation Research, Sahlgrenska Academy, University of Gothenburg, Gothenburg, \\ Sweden
}

The process of intercellular communication seems to have been a highly conserved evolutionary process. Higher eukaryotes use several means of intercellular communication to address both the changing physiological demands of the body and to fight against diseases. In recent years, there has been an increasing interest in understanding how cell-derived nanovesicles, known as extracellular vesicles (EVs), can function as normal paracrine mediators of intercellular communication, but can also elicit

OPEN ACCESS

Edited by:

Alexander N. Kapustin, King's College London, United Kingdom

Reviewed by: Leonardo Elia,

University of Brescia, Italy Luca Antonioli,

University of Pisa, Italy

Charlotte Lawson,

Royal Veterinary College, United Kingdom

*Correspondence:

Muhammad Nawaz

nawazm.edu@gmail.com orcid.org/0000-0002-0792-8296

Specialty section:

This article was submitted to

Cellular Biochemistry,

a section of the journal

Frontiers in Molecular Biosciences

Received: 25 May 2017

Accepted: 03 July 2017

Published: 18 July 2017

Citation:

Nawaz M and Fatima F (2017) Extracellular Vesicles, Tunneling Nanotubes, and Cellular Interplay:

Synergies and Missing Links.

Front. Mol. Biosci. 4:50

doi: 10.3389/fmolb.2017.00050 disease progression and may be used for innovative therapies. Over the last decade, a large body of evidence has accumulated to show that cells use cytoplasmic extensions comprising open-ended channels called tunneling nanotubes (TNTs) to connect cells at a long distance and facilitate the exchange of cytoplasmic material. TNTs are a different means of communication to classical gap junctions or cell fusions; since they are characterized by long distance bridging that transfers cytoplasmic organelles and intracellular vesicles between cells and represent the process of heteroplasmy. The role of EVs in cell communication is relatively well-understood, but how TNTs fit into this process is just emerging. The aim of this review is to describe the relationship between TNTs and EVs, and to discuss the synergies between these two crucial processes in the context of normal cellular cross-talk, physiological roles, modulation of immune responses, development of diseases, and their combinatory effects in tissue repair. At the present time this review appears to be the first summary of the implications of the overlapping roles of TNTs and EVs. We believe that a better appreciation of these parallel processes will improve our understanding on how these nanoscale conduits can be utilized as novel tools for targeted therapies.

Keywords: extracellular vesicles, exosomes, tunneling nanotubes, heteroplasmy, neurodegenerative diseases, viral infections, tumor progression, therapies

\section{INTRODUCTION}

Intercellular communication and the exchange of biological information between cells and organs is considered one of the sophisticated means of cellular coordination which modern eukaryotes have evolved to meet the needs of body physiology (Lai, 2004; Beckstead et al., 2006; Raft and Groves, 2015). Cells use different means of biological communication and signal transduction constituting direct physical contact between cells such as receptor-mediated interaction or cellular junctions between neighboring cells. Receptor-mediated cellular interactions are facilitated 
by certain transmembrane proteins and cell adhesion molecules such as integrins, tetraspanins, and cadherins (Hynes, 1992; Weber et al., 2011; Andreu and Yanez-Mo, 2014). The direct coupling of the cytoplasm of two cells through gap junctions (GJs) and concomitant transport of cytoplasmic material is also considered essential process in cellular cross-talk and is important for maintaining tissue homeostasis, development, and cellular differentiation (Schiller et al., 2001; Lim et al., 2011; Greco and Rameshwar, 2013; Munoz et al., 2013).

In the absence of direct physical contact, cells may convey biological messages in paracrine fashion through secreted factors such as cytokines, chemokines, and secreted growth factors (Sun et al., 2012; Tsuji and Kitamura, 2015). Therefore, the collateral effects of cells are not only reliant on direct cell-to-cell contact, but also to their transient paracrine actions through the release of a combination of trophic factors (Nawaz et al., 2016b). It is increasingly recognized that cells have evolved advanced forms of direct contact based communication and paracrine secreted factors. These include; (i) long range intercellular cytoplasmic bridges known as tunneling nanotubes (TNTs), and (ii) cell-derived nanovesicles known as extracellular vesicles (EVs). This review will illuminate biochemical, physiological, and pathological synergies between TNTs and EVs for their contribution in cellular communication and various pathological states.

\section{BIOGENESIS AND PHYSICOCHEMICAL ASPECTS OF EVS AND TNTS}

Cells secrete heterogeneous population of nanovesicles that differ in their origins, modes of biogenesis, morphologies and sizes. International Society for Extracellular Vesicles (ISEV) has designated a generalized term extracellular vesicles (EVs) to represent heterogeneous populations of vesicles (Mateescu et al., 2017). Based on their biogenesis and release pathways (Nawaz et al., 2014), EV populations are classified into exosomes $(40-120 \mathrm{~nm})$ which originate from endocytic pathway, and microvesicles or ectosomes $(100-1,000 \mathrm{~nm})$ that shed directly from the plasma membrane. Recently, larger membrane derived vesicles known as large oncosomes (1-10 $\mu \mathrm{m}$ diameter) have also been reported as discrete class of EVs (Di Vizio et al., 2012; Minciacchi et al., 2015). Moreover, the apoptotic bodies are occasionally considered as a part of nanovesicles which are produced by indiscriminate apoptotic disintegration and are designated as apoptotic vesicles. Each subtype of EVs undergoes distinct biogenesis pathway where several factors participate in biosynthesis, sorting, and maturation of various populations of EVs and their secretion into extracellular milieu (for detailed mechanisms see Nawaz et al., 2014).

EVs are composed of lipid bilayer which primarily include sphingolipids, cholesterol and ceramide components and appear to have round shape or cup shaped morphology when observed under scanning electron microscopy. EVs are best characterized by the presence of integrins and tetraspanins on their surface such as CD9, CD63, CD81, and the cytoplasmic heat shock protein HSP70, and other proteins characteristic of EV components such as GAPDH, Tsg101 and Alix (Keerthikumar et al., 2016). These molecules usually serve as EV detection markers. Additionally, EVs surface may contain major histocompatibility complexes (MHC) such as MHC-I and MHC-II and adhesion molecules. Collectively these molecules define characteristic composition of EV populations. However, the biomolecular contents such as nucleic acids proteins, and lipids encapsulated within EVs differ greatly between individual EV subtypes or between EVs obtained from various sources depending on type and state of secreting cell.

TNTs are actin-based transient cytoplasmic extensions which are stretched between cells in the form of open ended nanotubular channels (50-200 nm) discovered by Rustom and colleagues (Rustom et al., 2004). Like EVs, TNTs also represent subtypes and heterogeneous morphological structures (Austefjord et al., 2014; Benard et al., 2015). However, biosynthesis of TNTs differs from EVs and is attributed to factin polymerization (Gungor-Ordueri et al., 2015; OsteikoetxeaMolnar et al., 2016). The regulatory pathways of TNT formation and endosomal trafficking are overlapped, both involving the components of exocyst complex which regulates vesicular transport from Golgi apparatus to the plasma membrane (Kimura et al., 2013, 2016; Schiller et al., 2013a; Martin-Urdiroz et al., 2016). M-sec, part of the exocyst complex interacts with Ras-related protein-A (RalA, small GTPase) and is required for TNT formation (Hase et al., 2009; Zhao and Guo, 2009). M-Sec in cooperation with RalA and the exocyst complex serves as key factor for the formation of functional TNTs and therefore M-Sec is considered TNT marker (Ohno et al., 2010).

Other studies demonstrate that formation of some TNTs might be actinomyosin-dependent (Gurke et al., 2008b; Bukoreshtliev et al., 2009). Perhaps not surprising, motor proteins are required for the generation of some forms of TNTs. For instance, myosin10 (Myo10) is required for TNT formation from filapodia, where the overexpression of Myo10 results in increased TNT formation and vesicle transfer between cells (Gousset et al., 2013). Elevation of Eps8 (an actin regulatory protein) inhibits the extension of filopodia in neurons and increases TNT formation as well as intercellular vesicle transfer (Delage et al., 2016). Several other mechanisms and molecular basis of TNT formation have been recently described elsewhere (Kimura et al., 2012; Ranzinger et al., 2014; Desir et al., 2016; Weng et al., 2016). A recent study has revealed the presence of actin-like filaments in a subpopulation of EVs, indicating that some EVs may possess an intrinsic capacity to move (so called motile EVs; Cvjetkovic et al., 2017). Altogether, these observations indicate that cells may use motor proteins as component of both TNTs and EVs for shipping their cargo.

\section{TNTS AND EVS: SYNERGIES IN CARGO TRANSFER AND INTERCELLULAR COMMUNICATION}

EVs are currently gaining intensive focus of interest in understanding their role in intercellular communication and dissemination of bioactive cargo. However, the communication 
assisted via TNTs is less well-known, and indeed it is an interesting area of research. Interestingly, EVs are implicated in transporting biomolecules bidirectionally (Nawaz et al., 2016b), same do the TNTs (Lou et al., 2012). Both EVs and TNTs could facilitate long range communication between cells. EVs transport biological material in paracrine fashion i.e., secreted from one cell and transported to other cell, whereas TNTs transport biological material through cytoplasmic bridges between cells located at long distance (Figure 1; Onfelt et al., 2005; Gurke et al., 2008a; Zani and Edelman, 2010; Zhang, 2011; Wang and Gerdes, 2012; Valente et al., 2015; Fykerud et al., 2016). Therefore, TNTs serve a unique way of rapid communication between long distance cells in the form of direct cellular conduits and thus, are considered distinct from other mediators of cellcell communication or paracrine secreted factors (Frei et al., 2015).

EVs transport a repertoire of bioactive molecules such as lipids, proteins, and nucleic acids comprising genomic and mitochondrial DNA, mRNAs, miRNAs, and other ncRNAs (Fatima and Nawaz, 2015, 2017b). However, unlike EVs the TNTs are better known for shipping whole organelles by direct tubular connections between cells, such as mitochondria, lysosomes and Golgi vesicles (Rustom et al., 2002, 2004; Gerdes et al., 2007; Gurke et al., 2008b; Plotnikov et al., 2008; Wang and Gerdes, 2015; Han et al., 2016; Jackson et al., 2016; Torralba et al., 2016). The thicker subset of TNTs may range up to 0.7 microns (Onfelt et al., 2004; Benard et al., 2015), which is more favorable for the transport of larger organelles and lysosomal vesicles (Onfelt et al., 2006). TNTs also transport cytosolic $\mathrm{Ca}^{2+}$ and electrical signals to neighboring cells (Wang et al., 2010; Smith et al., 2011; Lock et al., 2016).

TNTs and EVs may exhibit the phenomenon of trogocytosis that is exchange of membrane fragments, for instance Fas$\mathrm{L}$ and MHC molecules (Luchetti et al., 2012; Fatima and Nawaz, 2017a). In addition, TNTs may transport $\mathrm{GM}_{1} / \mathrm{GM}_{3}$ (gangliosides) containing vesicles, as well as intercellular exchange of B7-2 (CD86) molecules and MHC-II which represent novel pathways of intercellular communication and immunoregulation (Osteikoetxea-Molnar et al., 2016). Although, TNTs are characteristically known for organelle transfer however, like EVs they could also transport proteins and signaling factors (Gallagher and Benfey, 2005; Reichert et al., 2016; Zhang N. et al., 2016), lipid droplets (Astanina et al., 2015), nucleic acids such as miRNAs (Thayanithy et al., 2014b; Climent et al., 2015), and double-stranded small interfering RNA (Antanaviciute et al., 2014).

Increasing body of evidence clarifies that both TNTs and EVs are observed from diverse cell types, including immune, neuronal, stromal, cancer, and stem cells indicating their diverse roles in various physiological and pathological conditions. Organelle transport via TNTs generally represents the states

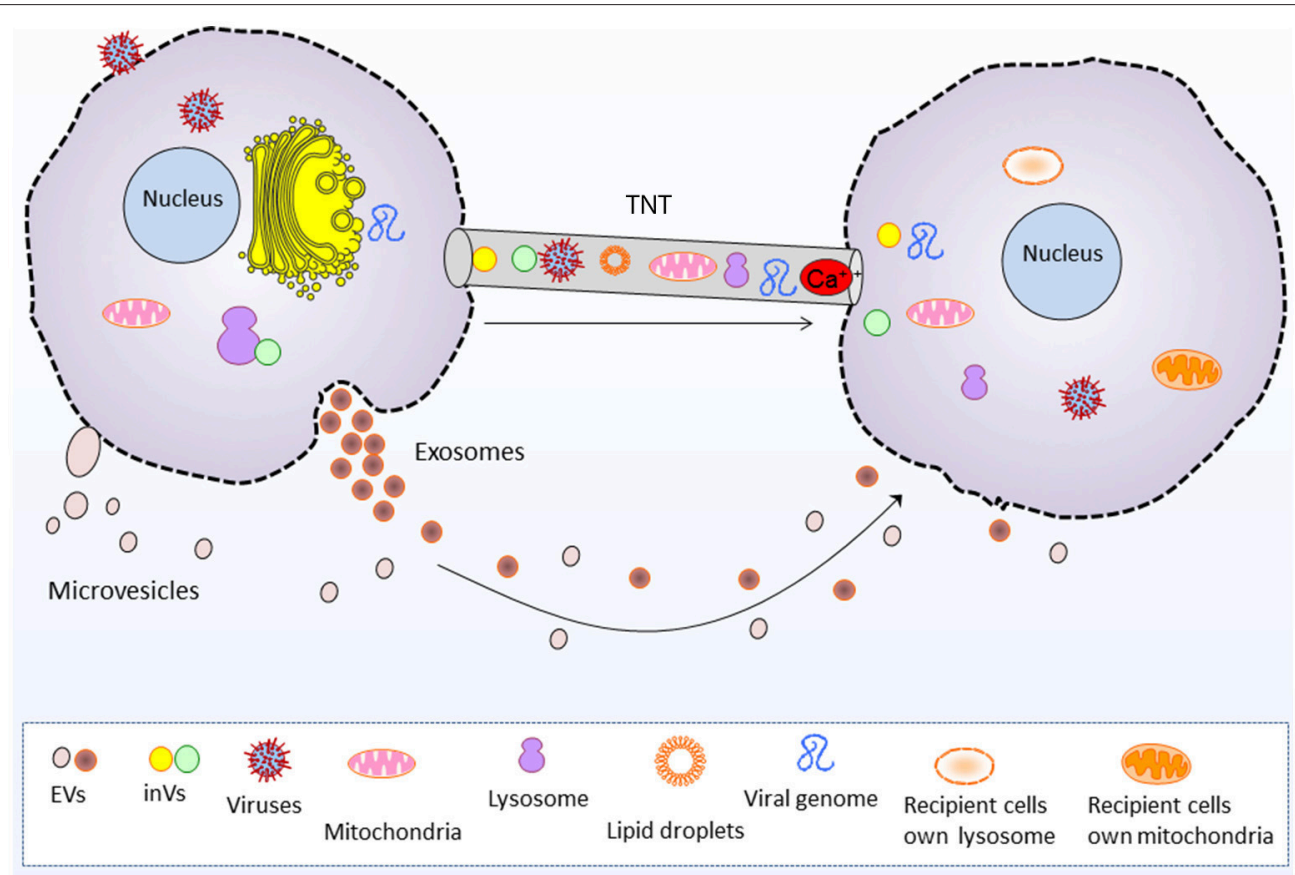

FIGURE 1 | Tunneling nanotubes and extracellular vesicle mediated intercellular communication and cargo transfer. Tunneling nanotubes transport cellular organelles such as mitochondria and lysosomes, as well as viruses, viral genome, lipid droplets, intera-cellular vesicles and Ca ${ }^{2+}$ and electrical signals. Whereas, extracellular vesicles (exosomes and microvesicles) transport nucleic acids, proteins and lipids between cells. EVs, Extracellular vesicles, inVs, intra-cellular vesicles i.e., Golgi vesicles and lysosomal vesicles. 
of heteroplasmy, redox/metabolic homeostasis, and the concomitant pathological conditions (will be discussed in next sections). Similarly, molecular transport via EVs represents phenotypic and functional changes in recipient cells. Therefore, dissemination of various forms of cytoplasmic cargo mediated by TNTs and EVs exhibits multifaceted roles in human physiology and pathological states including immunomodulation, infectious diseases, neurodegenerative disorders, cancer progression, cellular homeostasis, and repair process that will be discussed in sections below.

\section{TNTS AND EVS: ROLES IN IMMUNOREGULATION AND INFLAMMATORY RESPONSES}

Increasing body of evidence has demonstrated the contribution of EVs in immunomodulation and inflammatory responses both during normal physiology as well as pathological states (Zitvogel et al, 1998; Buzas et al., 2014; Robbins and Morelli, 2014; Nawaz et al., 2016a; Fatima and Nawaz, 2017a; Silva et al., 2017). However, the stimulatory roles of TNTs in cellular immunity are only recently beginning to be explored. TNTs have been shown to establish cytoplasmic bridges between variety of immune cells including human peripheral blood natural killer (NK) cells, EBV-transformed B-cells and the macrophages (Onfelt et al., 2004). Indeed, TNT formation in the context of immunity and inflammation such as antigen presentation (MHC complexes) has been widely reported in recent years (Chinnery et al., 2008; Schiller et al., 2013b; Seyed-Razavi et al., 2013; Campana et al., 2015; Osteikoetxea-Molnar et al., 2016). Arguably, such functional connectivity between immune cells may circumvent host defense against pathogens (Watkins and Salter, 2005; Zaccard et al., 2016).

Additionally, transfer of $\mathrm{H}$-ras from B-cells to T-cells indicates that TNTs may activate ras signaling and other stimulatory effects in recipient cells suggesting their implications for immunity (Rainy et al., 2013). TNTs between primary cultures of patient derived human peritoneal mesothelial cells may present pathophysiological conditions associated with distribution of cholesterol levels and may stimulate inflammatory reactions (Ranzinger et al., 2011). Interestingly, senescence cells communicate via TNTs to regulate their immune surveillance by NK-cells and are thought to impact tumorigenesis and tissue aging (Biran et al., 2015). In this context, EVs have also been proposed to contribute in the processes of senescence and aging (Lehmann et al., 2008; Patel et al., 2016; Urbanelli et al., 2016; Eitan et al., 2017; Takahashi et al., 2017; Prattichizzo et al., in press). Although, many of the biological features are similar between EVs and TNTs (McCoy-Simandle et al., 2016), however it remains unclear whether EVs and TNTs act simultaneously and cooperatively during intercellular communication in the context of immune regulation. However, these are newly described modes of conveying immune responses being different from classical theories of cellular immunology.

\section{RESEMBLANCE IN DISSEMINATION OF DISEASE ASSOCIATED PATTERNS}

\section{Neurodegenerative Diseases}

Both TNTs and EVs have been implicated in the spread of misfolded protein aggregates between different cells of central nervous system (CNS). For instance, Tau and other prion-like proteins promote the formation of TNTs between neurons and thus their own intercellular transfer via TNTs which results in prion-like propagation of Tau assemblies and propagation of neurodegenerative pathology (Figure 2A; Zhu et al., 2015; Abounit et al., 2016b; Tardivel et al., 2016). Astrocytes use intercellular transport by TNTs and EVs for delivering mitochondria and neuropathogenic protein aggregates respectively and serve as mediators in the pathogenesis of Alzheimer disease (Engel, 2014). Moreover, EVs and TNT-like structure could supply the routes for the transfer of transactive response DNA-binding protein of $43 \mathrm{kDa}$ (TDP-43) aggregates, whereas selective inhibition of their biosynthesis may interrupt the progression of TDP-43 proteinopathy (Ding et al., 2015). In fact, TDP-43 accumulation throughout the nervous system represents the development of neurodegenerative diseases such as amyotrophic lateral sclerosis and frontotemporal dementia (Ding et al., 2015). It has been proposed that intercellular dissemination of neuropathogenic proteins via TNTs could also cause damage to mitochondrial and/or mitochondrial DNA (mtDNA) in recipient cells and overall cellular degeneration (Agnati et al., 2010).

Additionally, fibrillar $\alpha$-synuclein ( $\alpha$-syn) aggregates in lysosomal vesicles are transported between neurons via TNTs indicating the role of TNTs and lysosomes in the progression of synucleinopathies (Abounit et al., 2016a). TNT serve as conduits for $\alpha$-syn transfer between non-neuronal cells during Parkinson's disease (Dieriks et al., 2017). Similarly, prion-infected astrocytes can disseminate prion (PrPSc) to neurons via TNTs and may contribute to disease progression (Victoria et al., 2016). In a way similar to viruses, the prions may highjack TNTs for spreading infectious agents such as PrPSc in neuronal cells (Gousset et al., 2009). Similar roles have been shown for EVs which transport $\alpha$-synuclein, $\beta$-amyloid, and PrPSc and contribute in neurodegenerative diseases (Rajendran et al., 2006; AlvarezErviti et al., 2011; Bellingham et al., 2012; Guo et al., 2016; Loov et al., 2016; Vella et al., 2016).

\section{TNTs and EVs: Novel Routes of Viral Infection}

Although, TNTs are characteristic of facilitating the exchange of organelles between cells, and pathogenic proteins from infected cells to naïve cells; however it remains unclear whether the viral genome is also transferred via TNTs and whether this route of transfer could result in replication of viral genome in the recipient cells. In this context, recent evidence show that influenza virus potentially exploits TNT networks for transferring viral proteins and the genome from infected to naive cells (Kumar et al., 2017). Authors argue that influenza uses these networks for evading immune and antiviral defenses and provide an explanation for the propagation of influenza 


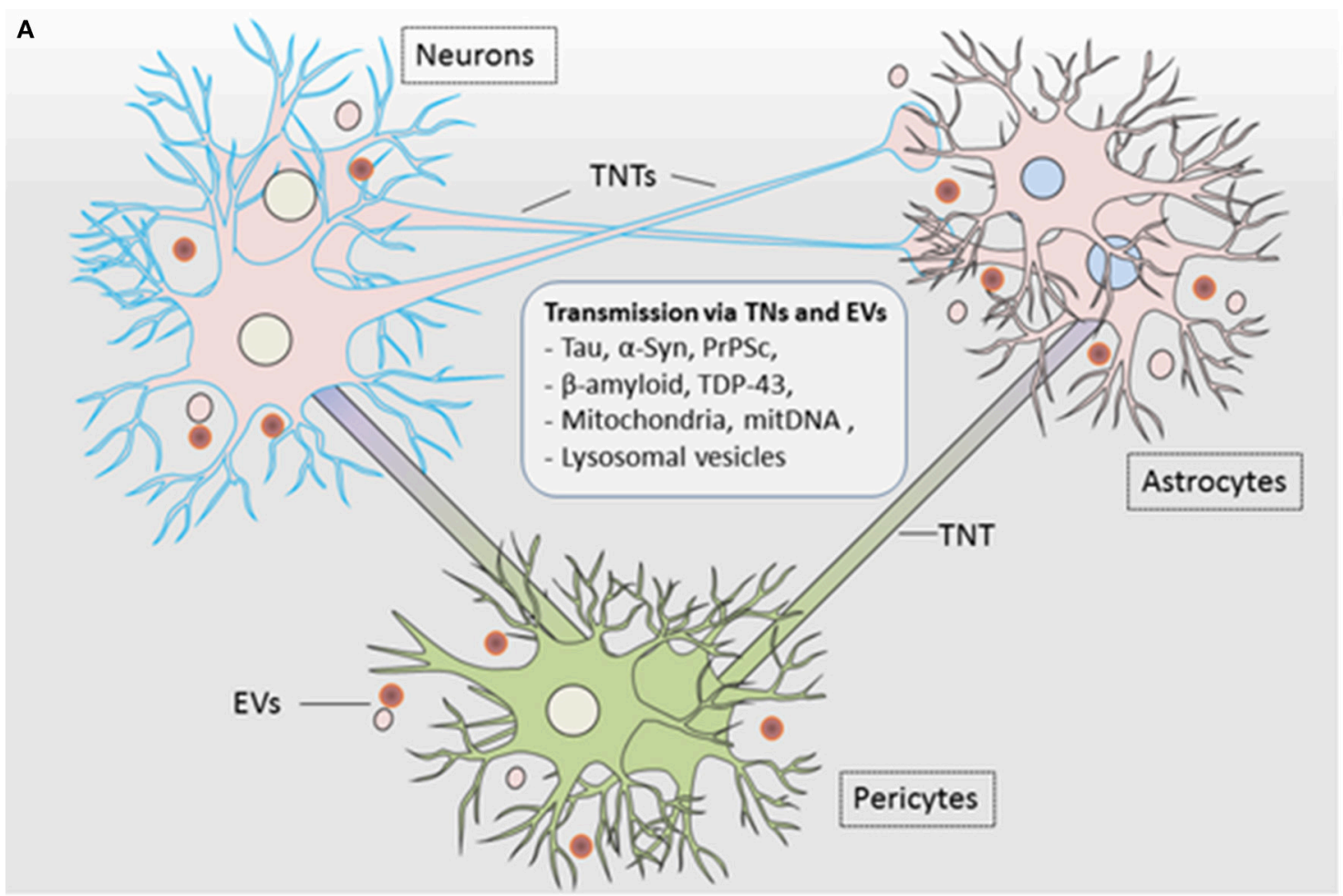

B

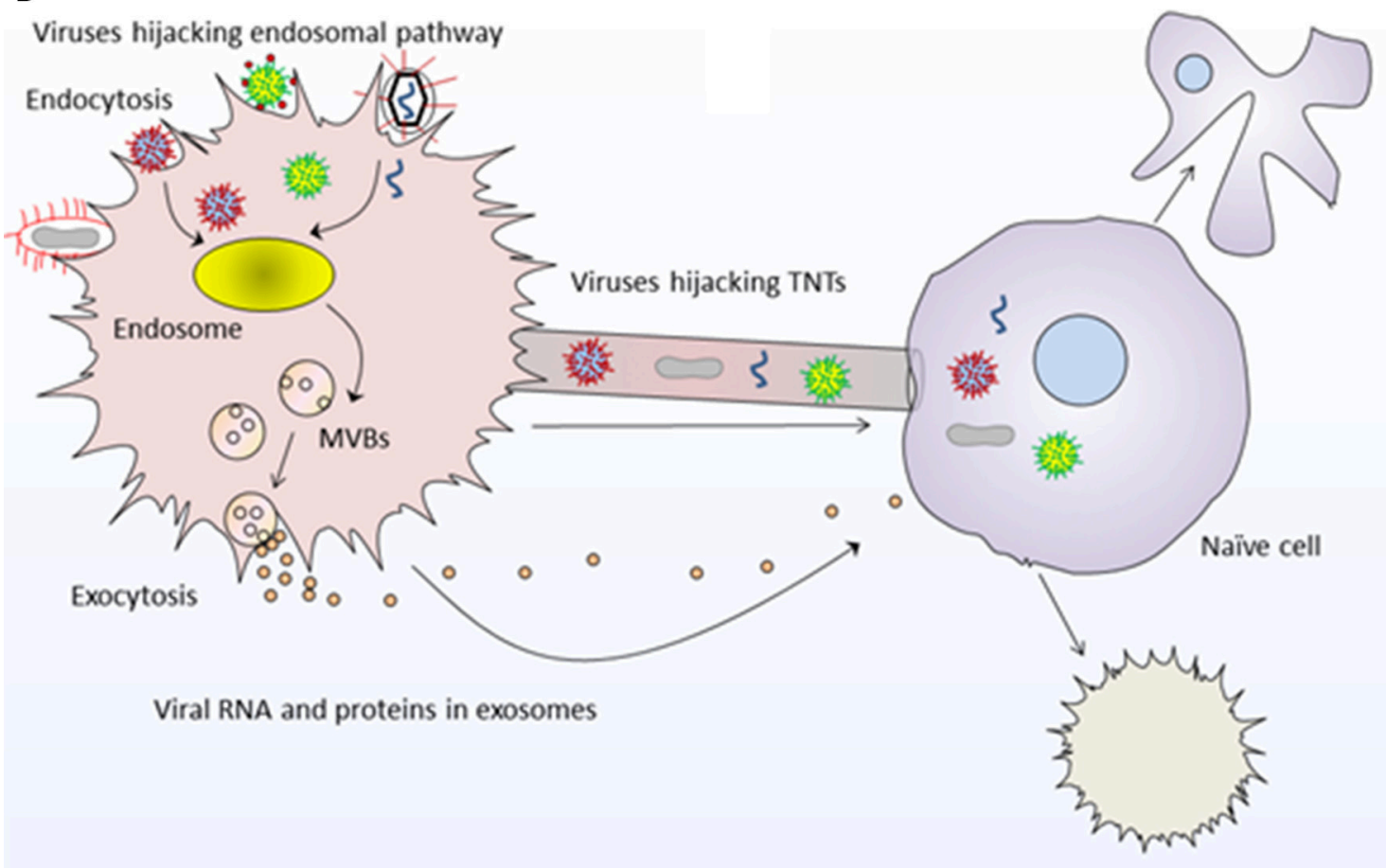

FIGURE 2 | Roles of tunneling nanotubes and extracellular vesicles in pathogenesis of diseases. (A) TNTs and EVs transport neuropathogenic proteins and genetic content between neurons, astrocytes and pericytes and result into neurodegenerative pathology such as tauopathies and synucleinopathies including Alzheimer and Parkinson's disease. (B) Viruses highjack both TNTs and EVs for the propagation of viral infection. Viral RNA/proteins are incorporated into EVs via endosomal pathway and are transferred to unaffected naive cells; whereas viruses may use direct transfer to naiive cells via TNTs. In both modes of propagation, the recipient cell may undergo cell death or transformed into infected cell pathology further spreading the infection to other cells. TNTs, Tunneling nanotubes; EVs, Extracellular vesicles. 
infections and vaccine failures. It has been shown that the icosahedral protein-rich membrane of virus could transform into a tubular structure (i.e., TNT), whereby internal diameter of the tube allows translocation of double-stranded DNA from one cell to the other (Peralta et al., 2013).

A protein encoded by the herpes simplex virus NV1066 named as enhanced green fluorescent protein (eGFP) was expressed in infected cells and transferred to uninfected recipient cells via TNTs. Particularly, the increased fluorescent activity was observed in recipient cells indicating the functional transmission of NV1066 virus expressed eGFP from affected to naïve cells (Ady et al., 2016). Moreover, following the viral thymidine kinase mediated activation of ganciclovir; TNTs could potentially mediate cell death as a form of direct cell-to-cell transfer. It is a unique form of long-range bystander effect underlying transmission of activated ganciclovir to nonvirus-infected cells. To this particular interest, authors argue that TNTs could be harnessed for the delivery of oncolytic viruses as well as viral thymidine kinase activated drugs in order to amplify the bystander effect between long distance cancer cells in a stromarich tumor microenvironments (Ady et al., 2016).

Cellular and molecular mechanisms that facilitate HIV infection in CNS could exploit the routes of intercellular communication via TNT for spreading the infection within CNS and may exhibit different forms of neuropathogenesis (Hazleton et al., 2010; Malik and Eugenin, 2016). It has been shown that HIV-infection of human macrophages induces the transient formation of short and long range TNTs, where distinct HIV vesicles are found to be localized in TNTs. This indicates that HIV hijacks TNTs communication to spread the pathogenesis of AIDS (Eugenin et al., 2009). Similarly, Retroviruses and Vaccinia virus could establish filopodial and TNT bridges between cells to spread the infection (Sherer and Mothes, 2008). TNTs have also been shown to facilitate HIV-1 transmission from activated T-cells to uninfected T-cells in a receptor-dependent manner (Sowinski et al., 2008, 2011). Transmission of HIV-1 via intercellular connections has been estimated far efficient than a cell-free process, perhaps in part explaining the persistent viral spread in the presence of neutralizing antibodies (Sowinski et al., 2008; Kumar et al., 2017). The coordination of exocyst complex and Nef protein (both are stimulators of TNT formation) is involved in polarized targeting for intercellular transfer of viruses and viral proteins (Mukerji et al., 2012; Hashimoto et al., 2016).

Like their role in TNTs, viruses could also highjack EVs for viral pathogenesis Figure 2B; Pegtel et al., 2010, 2011; Schwab et al., 2015; Nolte-'t Hoen et al., 2016; Sadeghipour and Mathias, 2017). In fact, viruses use EVs from their infected cells for delivering viral-RNA to uninfected cells, and this delivery is functional in recipient cells for the dissemination of viral infection (Pegtel et al., 2010). Interestingly, physical and chemical characteristics of biogenesis pathways of EVs resemble those of retroviruses, whereby viruses exploit the endosomal pathway for incorporating viral-RNA and viral-proteins into EVs being generated from virus-infected cells (Pegtel et al., 2011; Nolte-'t Hoen et al., 2016). Thus, viral factors from affected cells could be disseminated to uninfected cells via EVs and exhibit enhanced latent infection to surrounding cells (Schwab et al., 2015; Baglio et al., 2016).

\section{Resemblance in Cancer Progression}

There is increased interest in understanding how EVs may facilitate tumor progression, metastasis, and development of resistance against therapies. However, the discovery of TNTs sheds light on novel mechanisms for networking between cancer cells and represents alternative way of transferring cellular contents that confer cancer progression and/or resistance to therapies. Several cancer cell types, in particular malignant mesothelioma cells including primary malignant cells from human patients have been extensively reported to exhibit efficient way of communication by TNTs and implicated in dissemination of oncogenic content (Lou et al., 2012; Ady et al., 2014; Antanaviciute et al., 2014; Desir et al., 2016). Interestingly, when mesothelioma cells were co-cultured with exogenous mesothelioma-derived EVs, the cancer cells exhibited accelerated rate of TNT formation indicating that EVs impact the TNT formation (Thayanithy et al., 2014a).

Xenograft model of breast cancer using eGFP-expressing mice showed that transferrin receptor is transferred from tumor cells to stromal cells in-vivo and this process is strongly correlated with an increased opposite transfer of eGFP from stromal to tumor cells. This suggests that TNTs mediate complex intercellular communication between stromal elements within tumor niche (Burtey et al., 2015). Tumor stromal cross-talk could also be explained from potential of TNTs in transferring oncogenic miRNAs via direct connections between cells (Thayanithy et al., 2014b). The similar mode of stromal cross-talk has been shown by EVs (Fatima and Nawaz, 2015; Webber et al., 2015; Choi et al., 2017). Although, EVs are implicated in the transfer of oncogenic miRNAs between cells; however TNT-mediated transfer seems to be distinct form of inter-cellular transfer.

TNTs between astrocytes and glioma cells facilitate transfer of oncogenic material and alter the proliferation potential of glioma cells (Zhang and Zhang, 2015). Interestingly, there has been shown a positive correlation between TNT formation and EV release in glioblastoma cells against cocaine in a dose dependent manner (Carone et al., 2015). This indicates the combined contribution of TNT and EVs in intercellular communication and glial-neuronal plasticity and may participate in the processes associated with cocaine addiction. Recently, it has been reported that TNTs could transfer microsized particles, which were produced by cancer cells in response to radio therapy (Ware et al., 2015). Importantly, cancer cells may use TNTs for developing resistance to therapies by transferring Pglycoprotein and mitochondria (Pasquier et al., 2012, 2013). Like TNTs, EVs have also been extensively demonstrated for their roles in multidrug resistance owing to transfer of biomolecules between cells that foster recipient cell properties to resist chemo/radiotherapies (Fatima and Nawaz, 2017b).

Chemotherapies to acute myeloid leukemia (AML) such as cytarabine and daunorubicin treatment has been shown to inhibit TNT formation (Omsland et al., 2017). Interestingly, daunorubicin was found to localize to lysosomes within TNTs formed between AML cells indicating a novel function of TNTs 
as drug transporting devices. Similarly, primary B-cell precursor acute lymphoblastic leukemia (BCP-ALL) cells communicate with primary mesenchymal stromal cells (MSCs) via TNTs which stimulates the secretion of prosurvival cytokines (Polak et al., 2015). This indicates that TNT signaling is important for the viability of patient-derived BCP-ALL cells. Moreover, TNT guided signaling induces stroma-mediated prednisolone resistance in B-cell precursor ALL cells. This is a novel communication mechanism by which ALL cells modulate their bone marrow microenvironment. The identification of TNT signaling in ALL-MSC communication gives insight into the pathobiology of ALL and opens new avenues to develop more effective therapies that interfere with the leukemic niche.

\section{TNTS AND EVS: IMPLICATIONS IN REGENERATIVE/REPAIR PROCESSES}

The transfer of mitochondrial or mtDNA between mammalian cells including stem cells and mitochondria associated bioenergetics are increasingly being considered more dynamic process than previously thought (Spees et al., 2006; Rustom, 2016). MSCs are thought to transfer mitochondria to several different cell types including epithelial cells, endothelial cells, and cardiomyocytes (Plotnikov et al., 2008). In fact, such transfer may have positive effects on maintaining bioenergetics, enhancing cell survival, and ameliorating organ functions in conditions when mitochondria in resident cells are damaged and cells are facing oxidative stress. This includes the conditions of ischemic reperfusion, hypoxic or anaerobic conditions (Liu et al., 2014; Ham and Raju, in press), distressed cardiomyocytes and cardiomyopathy (Figeac et al., 2014; Yang et al., 2016; Zhang Y. et al., 2016), vascular injury (Vallabhaneni et al., 2012), intervertebral disc degeneration ( $\mathrm{Hu}$ et al., 2015), corneal injury (Chinnery et al., 2008; Jiang et al., 2016), airway injury and allergic airway inflammation (Ahmad et al., 2014), acute lung injury (Islam et al., 2012), and acute respiratory disease (Jackson et al., 2016). As such, TNT-mediated intercellular communication and mitochondria transfer between stem cells and injured cells have multipotential ways to persevere cell and organ integrity. Interestingly, EV-mediated intercellular communication between stem cells and injured cells and concomitant dissemination of prosurvival growth factors, and angiogenic factors via EVs have been extensively implicated in tissue repair and ameliorating organ function (Nawaz et al., 2016b).

The contribution of TNTs in lysosomal transfer from endothelial progenitor cells to stressed endothelial cells has been attributed in reducing premature senescence and vasorelaxation (Yasuda et al., 2011). This healing effect is preserved by reconstituting lysosomal pool of stressed cells. Additionally, multisystemic lysosomal storage disease (termed cystinosis) could be repaired by TNT-mediated cross-correction (Naphade et al., 2015). Therefore, transport of cystinosin-bearing lysosomes into cystinosin-deficient cells via TNTs is a potential way of repairing lysosomal disorders (Gaide Chevronnay et al., 2016).
TNT-mediated communication between MSCs and renal tubular cells with extensive spontaneous intercellular exchange of cytoplasmic material contributes to renal physiology (Plotnikov et al., 2010; Domhan et al., 2011; de Cavanagh et al., 2014), as has been shown by MSC-derived EVs (Grange et al., 2014; $\mathrm{Gu}$ et al., 2016). Similarly, the regulation of TNTs between neural stem cells and brain microvascular endothelial cells could rescue brain function (Wang et al., 2016). TNTs facilitate peripheral nerve regeneration through the regulation of neural cell communications (Zhu et al., 2016), the same do EVs (Ching and Kingham, 2015; Lopez-Leal and Court, 2016). It has been reported that ribosome recruitment to axons occurs via lateral transfer from glial cells, a mechanism that could be part of development and a continuum of intercellular communication systems including TNTs and EVs (Twiss and Fainzilber, 2009).

\section{CONCLUDING REMARKS AND FUTURE DIRECTIONS}

EVs are currently a focus of intensive interest in understanding their role in intercellular communication, dissemination of bioactive cargo, and their contribution in the progression of various diseases. Albeit, TNTs are comparatively less described nonetheless, they hold a great potential not only in studying cellular communication but also their multifaceted roles in disease progression and tissue repair. Given the fact that they transport organelles and regulate cellular bioenergetics; TNTs could be best exploited in treating organelle specific diseases in particular those associated with mitochondrial and lysosomal disorders.

Better understandings on the roles of nanotubes in tumorstromal cross-talk could help to identify new selective targets for cancer therapeutics. Therefore, interfering with central routes of intercellular cross-talk via these membranous cellular tubes and EVs in separate or simultaneously could offer strong potential to explore novel strategies for directed therapy. If we develop mechanistic insights into the formation of TNTs and release of EVs, modes of cargo transfer, and their functional consequences; TNTs and EVs might one day be used as vectors of drug delivery against multiple diseases.

\section{AUTHOR CONTRIBUTIONS}

Both authors participated in conceptualizing, writing, and critical review of the draft and agreed to final version before submission.

\section{ACKNOWLEDGMENTS}

We acknowledge, Dr. Jeremy A. Squire for language editing and valuable suggestions. MN acknowledges FAPESP (Sao Paulo Research Foundation, Proc. No. 12/24574-3), and CAPES (Coordination for the Improvement of Higher Education Personnel Brazil, Proc. No. 99999.007057/2015-06). FF acknowledges CAPES, Proc. No. 99999.006332/2015-03. 


\section{REFERENCES}

Abounit, S., Bousset, L., Loria, F., Zhu, S., de Chaumont, F., Pieri, L., et al. (2016a). Tunneling nanotubes spread fibrillar $\alpha$-synuclein by intercellular trafficking of lysosomes. EMBO J. 35, 2120-2138. doi: 10.15252/embj.201593411

Abounit, S., Wu, J. W., Duff, K., Victoria, G. S., and Zurzolo, C. (2016b). Tunneling nanotubes: a possible highway in the spreading of tau and other prion-like proteins in neurodegenerative diseases. Prion 10, 344-351. doi: $10.1080 / 19336896.2016 .1223003$

Ady, J., Thayanithy, V., Mojica, K., Wong, P., Carson, J., Rao, P., et al. (2016). Tunneling nanotubes: an alternate route for propagation of the bystander effect following oncolytic viral infection. Mol. Ther. Oncolytics 3:16029. doi: $10.1038 / \mathrm{mto} .2016 .29$

Ady, J. W., Desir, S., Thayanithy, V., Vogel, R. I., Moreira, A. L., Downey, R. J., et al. (2014). Intercellular communication in malignant pleural mesothelioma: properties of tunneling nanotubes. Front. Physiol. 5:400. doi: 10.3389/fphys.2014.00400

Agnati, L. F., Guidolin, D., Baluska, F., Leo, G., Barlow, P. W., Carone, C., et al. (2010). A new hypothesis of pathogenesis based on the divorce between mitochondria and their host cells: possible relevance for Alzheimer's disease. Curr. Alzheimer Res. 7, 307-322. doi: 10.2174/156720510791162395

Ahmad, T., Mukherjee, S., Pattnaik, B., Kumar, M., Singh, S., Kumar, M., et al. (2014). Mirol regulates intercellular mitochondrial transport \& enhances mesenchymal stem cell rescue efficacy. EMBO J. 33, 994-1010. doi: $10.1002 / \mathrm{embj} .201386030$

Alvarez-Erviti, L., Seow, Y., Schapira, A. H., Gardiner, C., Sargent, I. L., Wood, M. J., et al. (2011). Lysosomal dysfunction increases exosome-mediated alpha-synuclein release and transmission. Neurobiol. Dis. 42, 360-367. doi: 10.1016/j.nbd.2011.01.029

Andreu, Z., and Yanez-Mo, M. (2014). Tetraspanins in extracellular vesicle formation and function. Front. Immunol. 5:442. doi: 10.3389/fimmu. 2014.00442

Antanaviciute, I., Rysevaite, K., Liutkevicius, V., Marandykina, A., Rimkute, L., Sveikatiene, R., et al. (2014). Long-distance communication between laryngeal carcinoma cells. PLoS ONE 9:e99196. doi: 10.1371/journal.pone. 0099196

Astanina, K., Koch, M., Jungst, C., Zumbusch, A., and Kiemer, A. K. (2015). Lipid droplets as a novel cargo of tunnelling nanotubes in endothelial cells. Sci. Rep. 5:11453. doi: $10.1038 /$ srep 11453

Austefjord, M. W., Gerdes, H. H., and Wang, X. (2014). Tunneling nanotubes: diversity in morphology and structure. Commun. Integr. Biol. 7:e27934. doi: 10.4161/cib.27934

Baglio, S. R., van Eijndhoven, M. A., Koppers-Lalic, D., Berenguer, J., Lougheed, S. M., Gibbs, S., et al. (2016). Sensing of latent EBV infection through exosomal transfer of 5'pppRNA. Proc. Natl. Acad. Sci. U.S.A. 113, E587-E596. doi: 10.1073/pnas.1518130113

Beckstead, B. L., Santosa, D. M., and Giachelli, C. M. (2006). Mimicking cellcell interactions at the biomaterial-cell interface for control of stem cell differentiation. J. Biomed. Mater. Res. A 79, 94-103. doi: 10.1002/jbm.a. 30760

Bellingham, S. A., Guo, B. B., Coleman, B. M., and Hill, A. F. (2012). Exosomes: vehicles for the transfer of toxic proteins associated with neurodegenerative diseases? Front. Physiol. 3:124. doi: 10.3389/fphys.2012.00124

Benard, M., Schapman, D., Lebon, A., Monterroso, B., Bellenger, M., Le Foll, F., et al. (2015). Structural and functional analysis of tunneling nanotubes (TnTs) using gCW STED and gconfocal approaches. Biol. Cell 107, 419-425. doi: 10.1111/boc.201500004

Biran, A., Perelmutter, M., Gal, H., Burton, D. G., Ovadya, Y., Vadai, E., et al. (2015). Senescent cells communicate via intercellular protein transfer. Genes Dev. 29, 791-802. doi: 10.1101/gad.259341.115

Bukoreshtliev, N. V., Wang, X., Hodneland, E., Gurke, S., Barroso, J. F., and Gerdes, H. H. (2009). Selective block of tunneling nanotube (TNT) formation inhibits intercellular organelle transfer between PC12 cells. FEBS Lett. 583, 1481-1488. doi: 10.1016/j.febslet.2009.03.065

Burtey, A., Wagner, M., Hodneland, E., Skaftnesmo, K. O., Schoelermann, J., Mondragon, I. R., et al. (2015). Intercellular transfer of transferrin receptor by a contact-, Rab8-dependent mechanism involving tunneling nanotubes. FASEB J. 29, 4695-4712. doi: 10.1096/fj.14-268615
Buzas, E. I., Gyorgy, B., Nagy, G., Falus, A., and Gay, S. (2014). Emerging role of extracellular vesicles in inflammatory diseases. Nat. Rev. Rheumatol. 10, 356-364. doi: 10.1038/nrrheum.2014.19

Campana, S., De Pasquale, C., Carrega, P., Ferlazzo, G., and Bonaccorsi, I. (2015). Cross-dressing: an alternative mechanism for antigen presentation. Immunol. Lett. 168, 349-354. doi: 10.1016/j.imlet.2015. 11.002

Carone, C., Genedani, S., Leo, G., Filaferro, M., Fuxe, K., and Agnati, L. F. (2015). In vitro effects of cocaine on tunneling nanotube formation and extracellular vesicle release in glioblastoma cell cultures. J. Mol. Neurosci. 55, 42-50. doi: 10.1007/s12031-014-0365-9

Ching, R. C., and Kingham, P. J. (2015). The role of exosomes in peripheral nerve regeneration. Neural Regen. Res. 10, 743-747. doi: 10.4103/1673-5374.156968

Chinnery, H. R., Pearlman, E., and McMenamin, P. G. (2008). Cutting edge: membrane nanotubes in vivo: a feature of MHC class II+ cells in the mouse cornea. J. Immunol. 180, 5779-5783. doi: 10.4049/jimmunol.180.9.5779

Choi, D., Lee, T. H., Spinelli, C., Chennakrishnaiah, S., D'Asti, E., and Rak, J. (2017). Extracellular vesicle communication pathways as regulatory targets of oncogenic transformation. Semin. Cell Dev. Biol. 67, 11-22. doi: 10.1016/j.semcdb.2017.01.003

Climent, M., Quintavalle, M., Miragoli, M., Chen, J., Condorelli, G., and Elia, L. (2015). TGFbeta triggers miR-143/145 transfer from smooth muscle cells to endothelial cells, thereby modulating vessel stabilization. Circ. Res. 116, 1753-1764. doi: 10.1161/CIRCRESAHA.116.305178

Cvjetkovic, A., Crescitelli, R., Lässer, C., Zabeo, D., Widlund, P., Nyström, T., et al. (2017). Extracellular vesicles in motion. Matters. doi: 10.19185/matters.201704000003

de Cavanagh, E. M., Gonzalez, S. A., Inserra, F., Forcada, P., Castellaro, C., Chiabaut-Svane, J., et al. (2014). Sympathetic predominance is associated with impaired endothelial progenitor cells and tunneling nanotubes in controlledhypertensive patients. Am. J. Physiol. Heart Circ. Physiol. 307, H207-H215. doi: 10.1152/ajpheart.00955.2013

Delage, E., Cervantes, D. C., Penard, E., Schmitt, C., Syan, S., Disanza, A., et al. (2016). Differential identity of Filopodia and Tunneling Nanotubes revealed by the opposite functions of actin regulatory complexes. Sci. Rep. 6:39632. doi: $10.1038 /$ srep39632

Desir, S., Dickson, E. L., Vogel, R. I., Thayanithy, V., Wong, P., Teoh, D., et al. (2016). Tunneling nanotube formation is stimulated by hypoxia in ovarian cancer cells. Oncotarget 7, 43150-43161. doi: 10.18632/oncotarget.9504

Dieriks, B. V., Park, T. I., Fourie, C., Faull, R. L., Dragunow, M., and Curtis, M. A. (2017). $\alpha$-synuclein transfer through tunneling nanotubes occurs in SH-SY5Y cells and primary brain pericytes from Parkinson's disease patients. Sci. Rep. 7:42984. doi: 10.1038/srep42984

Ding, X., Ma, M., Teng, J., Teng, R. K., Zhou, S., Yin, J., et al. (2015). Exposure to ALS-FTD-CSF generates TDP-43 aggregates in glioblastoma cells through exosomes and TNTs-like structure. Oncotarget 6, 24178-24191. doi: 10.18632 /oncotarget. 4680

Di Vizio, D., Morello, M., Dudley, A. C., Schow, P. W., Adam, R. M., Morley, S., et al. (2012). Large oncosomes in human prostate cancer tissues and in the circulation of mice with metastatic disease. Am. J. Pathol. 181, 1573-1584. doi: 10.1016/j.ajpath.2012.07.030

Domhan, S., Ma, L., Tai, A., Anaya, Z., Beheshti, A., Zeier, M., et al. (2011). Intercellular communication by exchange of cytoplasmic material via tunneling nano-tube like structures in primary human renal epithelial cells. PLOS ONE 6:e21283. doi: 10.1371/journal.pone.0021283

Eitan, E., Green, J., Bodogai, M., Mode, N. A., Baek, R., Jorgensen, M. M., et al. (2017). Age-Related Changes in Plasma Extracellular Vesicle Characteristics and Internalization by Leukocytes. Sci. Rep. 7:1342. doi: 10.1038/s41598-017-01386-Z

Engel, P. A. (2014). Does metabolic failure at the synapse cause Alzheimer's disease? Med. Hypotheses Med. 83, 802-808. doi: 10.1016/j.mehy.2014.10.013

Eugenin, E. A., Gaskill, P. J., and Berman, J. W. (2009). Tunneling nanotubes (TNT) are induced by HIV-infection of macrophages: a potential mechanism for intercellular HIV trafficking. Cell Immunol. 254, 142-148. doi: 10.1016/i.cellimm.2008.08.005

Fatima, F., and Nawaz, M. (2015). Stem cell-derived exosomes: roles in stromal remodeling, tumor progression, and cancer immunotherapy. Chin. J. Cancer 34, 541-553. doi: 10.1186/s40880-015-0051-5 
Fatima, F., and Nawaz, M. (2017a). Nexus between extracellular vesicles, immunomodulation and tissue remodeling: for good or for bad? Ann. Transl. Med. 5:139. doi: 10.3390/ncrna3010010

Fatima, F., and Nawaz, M. (2017b). Vesiculated long non-coding RNAs: offshore packages deciphering trans-regulation between cells, cancer progression and resistance to therapies. Non Coding RNA 3:10. doi: 10.3390/ncrna3010010

Figeac, F., Lesault, P. F., Le Coz, O., Damy, T., Souktani, R., Trebeau, C., et al. (2014). Nanotubular crosstalk with distressed cardiomyocytes stimulates the paracrine repair function of mesenchymal stem cells. Stem Cells 32, 216-230. doi: $10.1002 /$ stem. 1560

Frei, D. M., Hodneland, E., Rios-Mondragon, I., Burtey, A., Neumann, B., Bulkescher, J., et al. (2015). Novel microscopy-based screening method reveals regulators of contact-dependent intercellular transfer. Sci. Rep. Sci. 5:12879. doi: $10.1038 /$ srep 12879

Fykerud, T. A., Knudsen, L. M., Totland, M. Z., Sorensen, V., DahalKoirala, S., Lothe, R. A., et al. (2016). Mitotic cells form actin-based bridges with adjacent cells to provide intercellular communication during rounding. Cell Cycle 15, 2943-2957. doi: 10.1080/15384101.2016. 1231280

Gaide Chevronnay, H. P., Janssens, V., Van Der Smissen, P., Rocca, C. J., Liao, X. H., Refetoff, S., et al. (2016). Hematopoietic stem cells transplantation can normalize thyroid function in a cystinosis mouse Model. Endocrinology 157, 1363-1371. doi: 10.1210/en.2015-1762

Gallagher, K. L., and Benfey, P. N. (2005). Not just another hole in the wall: understanding intercellular protein trafficking. Genes Dev. 19, 189-195. doi: $10.1101 /$ gad. 1271005

Gerdes, H. H., Bukoreshtliev, N. V., and Barroso, J. F. (2007). Tunneling nanotubes: a new route for the exchange of components between animal cells. FEBS Lett. 581, 2194-2201. doi: 10.1016/j.febslet.2007.03.071

Gousset, K., Marzo, L., Commere, P. H., and Zurzolo, C. (2013). Myo10 is a key regulator of TNT formation in neuronal cells. J. Cell Sci. 126(Pt 19), 4424-4435. doi: $10.1242 /$ jcs. 129239

Gousset, K., Schiff, E., Langevin, C., Marijanovic, Z., Caputo, A., Browman, D. T., et al. (2009). Prions hijack tunnelling nanotubes for intercellular spread. Nat. Cell Biol. 11, 328-336. doi: 10.1038/ncb1841

Grange, C., Tapparo, M., Bruno, S., Chatterjee, D., Quesenberry, P. J., Tetta, C., et al. (2014). Biodistribution of mesenchymal stem cell-derived extracellular vesicles in a model of acute kidney injury monitored by optical imaging. Int. J. Mol. Med. 33, 1055-1063. doi: 10.3892/ijmm.2014.1663

Greco, S. J., and Rameshwar, P. (2013). Analysis of the transfer of circulating microRNA between cells mediated by gap junction. Methods Mol. Biol. 1024, 87-96. doi: 10.1007/978-1-62703-453-1_7

Gu, D., Zou, X., Ju, G., Zhang, G., Bao, E., and Zhu, Y. (2016). Mesenchymal stromal cells derived extracellular vesicles ameliorate acute renal ischemia reperfusion injury by inhibition of mitochondrial fission through miR-30. Stem Cells Int. 2016:2093940. doi: 10.1155/2016/2093940

Gungor-Ordueri, N. E., Celik-Ozenci, C., and Cheng, C. Y. (2015). Ezrin: a regulator of actin microfilaments in cell junctions of the rat testis. Asian J. Androl. 17, 653-658. doi: 10.4103/1008-682X.146103

Guo, B. B., Bellingham, S. A., and Hill, A. F. (2016). Stimulating the release of exosomes increases the intercellular transfer of prions. J. Biol. Chem. 291, 5128-5137. doi: 10.1074/jbc.M115.684258

Gurke, S., Barroso, J. F., and Gerdes, H. H. (2008a). The art of cellular communication: tunneling nanotubes bridge the divide. Histochem. Cell Biol. 129, 539-550. doi: 10.1007/s00418-008-0412-0

Gurke, S., Barroso, J. F., Hodneland, E., Bukoreshtliev, N. V., Schlicker, O., and Gerdes, H. H. (2008b). Tunneling nanotube (TNT)-like structures facilitate a constitutive, actomyosin-dependent exchange of endocytic organelles between normal rat kidney cells. Exp. Cell Res. 314, 3669-3683. doi: 10.1016/j.yexcr.2008.08.022

Ham, P. B. III, and Raju, R. (in press). Mitochondrial function in hypoxic ischemic injury and influence of aging. Prog. Neurobiol. doi: 10.1016/j.pneurobio.2016.06.006

Han, H., Hu, J., Yan, Q., Zhu, J., Zhu, Z., Chen, Y., et al. (2016). Bone marrow-derived mesenchymal stem cells rescue injured $\mathrm{H} 9 \mathrm{c} 2$ cells via transferring intact mitochondria through tunneling nanotubes in an in vitro simulated ischemia/reperfusion model. Mol. Med. Rep. 13, 1517-1524. doi: $10.3892 / \mathrm{mmr} .2015 .4726$
Hase, K., Kimura, S., Takatsu, H., Ohmae, M., Kawano, S., Kitamura, H., et al. (2009). M-Sec promotes membrane nanotube formation by interacting with Ral and the exocyst complex. Nat. Cell Biol. 11, 1427-1432. doi: 10.1038/ ncb1990

Hashimoto, M., Bhuyan, F., Hiyoshi, M., Noyori, O., Nasser, H., Miyazaki, M., et al. (2016). Potential role of the formation of tunneling nanotubes in HIV1 spread in Macrophages. J. Immunol. 196, 1832-1841. doi: 10.4049/jimmunol. 1500845

Hazleton, J. E., Berman, J. W., and Eugenin, E. A. (2010). Novel mechanisms of central nervous system damage in HIV infection. HIV AIDS 2, 39-49. doi: 10.2147/HIV.S9186

Hu, J., Deng, G., Tian, Y., Pu, Y., Cao, P., and Yuan, W. (2015). An in vitro investigation into the role of bone marrowderived mesenchymal stem cells in the control of disc degeneration. Mol. Med. Rep. 12, 5701-5708. doi: 10.3892/mmr.2015.4139

Hynes, R. O. (1992). Integrins: versatility, modulation, and signaling in cell adhesion. Cell 69, 11-25. doi: 10.1016/0092-8674(92)90115-S

Islam, M. N., Das, S. R., Emin, M. T., Wei, M., Sun, L., Westphalen, K., et al. (2012). Mitochondrial transfer from bone-marrow-derived stromal cells to pulmonary alveoli protects against acute lung injury. Nat. Med. 18, 759-765. doi: $10.1038 / \mathrm{nm} .2736$

Jackson, M. V., Morrison, T. J., Doherty, D. F., McAuley, D. F., Matthay, M. A., Kissenpfennig, A., et al. (2016). Mitochondrial transfer via tunneling nanotubes is an important mechanism by which mesenchymal stem cells enhance macrophage phagocytosis in the in vitro and in vivo models of ARDS. Stem Cells 34, 2210-2223. doi: 10.1002/stem.2372

Jiang, D., Gao, F., Zhang, Y., Wong, D. S., Li, Q., Tse, H. F., et al. (2016). Mitochondrial transfer of mesenchymal stem cells effectively protects corneal epithelial cells from mitochondrial damage. Cell Death Dis. 7:e2467. doi: $10.1038 /$ cddis.2016.358

Keerthikumar, S., Chisanga, D. Ariyaratne, D., Al Saffar, H., Anand, S., Zhao, K., et al. (2016). ExoCarta: a web-based compendium of exosomal cargo. J. Mol. Biol. 428, 688-692. doi: 10.1016/j.jmb.2015.09.019

Kimura, S., Hase, K., and Ohno, H. (2012). Tunneling nanotubes: emerging view of their molecular components and formation mechanisms. Exp. Cell Res. 318, 1699-1706. doi: 10.1016/j.yexcr.2012.05.013

Kimura, S., Hase, K., and Ohno, H. (2013). The molecular basis of induction and formation of tunneling nanotubes. Cell Tissue Res. 352, 67-76. doi: 10.1007/s00441-012-1518-1

Kimura, S., Yamashita, M., Yamakami-Kimura, M., Sato, Y., Yamagata, A., Kobashigawa, Y., et al. (2016). Distinct roles for the $\mathrm{n}$ - and c-terminal regions of $\mathrm{m}$-sec in plasma membrane deformation during tunneling nanotube formation. Sci. Rep. 6:33548. doi: 10.1038/srep33548

Kumar, A., Kim, J. H., Ranjan, P., Metcalfe, M. G., Cao, W., Mishina, M., et al. (2017). Influenza virus exploits tunneling nanotubes for cell-to-cell spread. Sci. Rep. 7:40360. doi: 10.1038/srep40360

Lai, E. C. (2004). Notch signaling: control of cell communication and cell fate. Development 131, 965-973. doi: 10.1242/dev.01074

Lehmann, B. D., Paine, M. S., Brooks, A. M., McCubrey, J. A., Renegar, R. H., Wang, R., et al. (2008). Senescence-associated exosome release from human prostate cancer cells. Cancer Res. 68, 7864-7871. doi: 10.1158/0008-5472.CAN-07-6538

Lim, P. K., Bliss, S. A., Patel, S. A., Taborga, M., Dave, M. A., Gregory, L. A., et al. (2011). Gap junction-mediated import of microRNA from bone marrow stromal cells can elicit cell cycle quiescence in breast cancer cells. Cancer Res. 71, 1550-1560. doi: 10.1158/0008-5472.CAN-10-2372

Liu, K., Ji, K., Guo, L., Wu, W., Lu, H., Shan, P., et al. (2014). Mesenchymal stem cells rescue injured endothelial cells in an in vitro ischemia-reperfusion model via tunneling nanotube like structure-mediated mitochondrial transfer. Microvasc. Res. 92, 10-18. doi: 10.1016/j.mvr.2014.01.008

Lock, J. T., Parker, I., and Smith, I. F. (2016). Communication of $\mathrm{Ca}^{2+}$ signals via tunneling membrane nanotubes is mediated by transmission of inositol trisphosphate through gap junctions. Cell Calcium 60, 266-272. doi: 10.1016/j.ceca.2016.06.004

Loov, C., Scherzer, C. R., Hyman, B. T., Breakefield, X. O., and Ingelsson, M. (2016). $\alpha$-synuclein in extracellular vesicles: functional implications and diagnostic opportunities. Cell Mol. Neurobiol. 36, 437-448. doi: 10.1007/s10571-015-0317-0 
Lopez-Leal, R., and Court, F. A. (2016). Schwann cell exosomes mediate neuronglia communication and enhance axonal regeneration. Cell Mol. Neurobiol. 36, 429-436. doi: 10.1007/s10571-015-0314-3

Lou, E., Fujisawa, S., Morozov, A., Barlas, A., Romin, Y., Dogan, Y., et al. (2012). Tunneling nanotubes provide a unique conduit for intercellular transfer of cellular contents in human malignant pleural mesothelioma. PLoS ONE 7:e33093. doi: 10.1371/journal.pone.0033093

Luchetti, F., Canonico, B., Arcangeletti, M., Guescini, M., Cesarini, E., Stocchi, V., et al. (2012). Fas signalling promotes intercellular communication in $\mathrm{T}$ cells. PLOS ONE 7:e35766. doi: 10.1371/journal.pone.0035766

Malik, S., and Eugenin, E. A. (2016). Mechanisms of HIV neuropathogenesis: role of cellular communication systems. Curr. HIV Res. 14, 400-411. doi: 10.2174/1570162X14666160324124558

Martin-Urdiroz, M., Deeks, M. J., Horton, C. G., Dawe, H. R., and Jourdain, I. (2016). The exocyst complex in health and disease. Front. Cell Dev. Biol. 4:24. doi: $10.3389 /$ fcell.2016.00024

Mateescu, B., Kowal, E. J., van Balkom, B. W., Bartel, S., Bhattacharyya, S. N., Buzas, E. I., et al. (2017). Obstacles and opportunities in the functional analysis of extracellular vesicle RNA - an ISEV position paper. J. Extracell. Vesicles 6:1286095. doi: 10.1080/20013078.2017.1286095

McCoy-Simandle, K., Hanna, S. J., and Cox, D. (2016). Exosomes and nanotubes: control of immune cell communication. Int. J. Biochem. Cell Biol. 71, 44-54. doi: 10.1016/j.biocel.2015.12.006

Minciacchi, V. R., Freeman, M. R., and Di Vizio, D. (2015). Extracellular vesicles in cancer: exosomes, microvesicles and the emerging role of large oncosomes. Semin. Cell Dev. Biol. 40, 41-51. doi: 10.1016/j.semcdb.2015.02.010

Mukerji, J., Olivieri, K. C., Misra, V., Agopian, K. A., and Gabuzda, D. (2012). Proteomic analysis of HIV-1 Nef cellular binding partners reveals a role for exocyst complex proteins in mediating enhancement of intercellular nanotube formation. Retrovirology 9:33. doi: 10.1186/1742-4690-9-33

Munoz, J. L., Bliss, S. A., Greco, S. J., Ramkissoon, S. H., Ligon, K. L., and Rameshwar, P. (2013). Delivery of functional Anti-miR-9 by mesenchymal stem cell-derived exosomes to glioblastoma multiforme cells conferred chemosensitivity. Mol. Ther. Nucleic Acids 2:e126. doi: 10.1038/mtna.2013.60

Naphade, S., Sharma, J., Gaide Chevronnay, H. P., Shook, M. A., Yeagy, B. A., Rocca, C. J., et al. (2015). Brief reports: lysosomal cross-correction by hematopoietic stem cell-derived macrophages via tunneling nanotubes. Stem Cells 33, 301-309. doi: 10.1002/stem.1835

Nawaz, M., Camussi, G., Valadi, H., Nazarenko, I., Ekstrom, K., Wang, X., et al. (2014). The emerging role of extracellular vesicles as biomarkers for urogenital cancers. Nat. Rev. Urol. 11, 688-701. doi: 10.1038/nrurol.2014.301

Nawaz, M., Fatima, F., Nazarenko, I., Ekstrom, K., Murtaza, I., Anees, M., et al. (2016a). Extracellular vesicles in ovarian cancer: applications to tumor biology, immunotherapy and biomarker discovery. Expert Rev. Proteomics 13, 395-409. doi: $10.1586 / 14789450.2016 .1165613$

Nawaz, M., Fatima, F., Vallabhaneni, K. C., Penfornis, P., Valadi, H., Ekstrom, K., et al. (2016b). Extracellular vesicles: evolving factors in stem cell biology. Stem Cells Int. 2016:1073140. doi: 10.1155/2016/1073140

Nolte-'t Hoen, E., Cremer, T., Gallo, R. C., and Margolis, L. B. (2016). Extracellular vesicles and viruses: are they close relatives? Proc. Natl. Acad. Sci. U.S.A. 113, 9155-9161. doi: 10.1073/pnas.1605146113

Ohno, H., Hase, K., and Kimura, S. (2010). M-Sec: emerging secrets of tunneling nanotube formation. Commun. Integr. Biol. 3, 231-233. doi: $10.4161 /$ cib.3.3.11242

Omsland, M., Bruserud, O., Gjertsen, B. T., and Andresen, V. (2017). Tunneling nanotube (TNT) formation is downregulated by cytarabine and NF- $\kappa B$ inhibition in acute myeloid leukemia (AML). Oncotarget 8, 7946-7963. doi: 10.18632 /oncotarget.13853

Onfelt, B., Nedvetzki, S., Benninger, R. K., Purbhoo, M. A., Sowinski, S., Hume, A. N., et al. (2006). Structurally distinct membrane nanotubes between human macrophages support long-distance vesicular traffic or surfing of bacteria. J. Immunol. 177, 8476-8483. doi: 10.4049/jimmunol.177.12.8476

Onfelt, B., Nedvetzki, S., Yanagi, K., and Davis, D. M. (2004). Cutting edge: membrane nanotubes connect immune cells. J. Immunol. 173, 1511-1513. doi: 10.4049/jimmunol.173.3.1511

Onfelt, B., Purbhoo, M. A., Nedvetzki, S., Sowinski, S., and Davis, D. M. (2005). Long-distance calls between cells connected by tunneling nanotubules. Sci. STKE 2005:pe55. doi: 10.1126/stke.3132005pe55
Osteikoetxea-Molnar, A., Szabo-Meleg, E., Toth, E. A., Oszvald, A., Izsepi, E., Kremlitzka, M., et al. (2016). The growth determinants and transport properties of tunneling nanotube networks between B lymphocytes. Cell Mol. Life Sci. 73, 4531-4545. doi: 10.1007/s00018-016-2233-y

Pasquier, J., Galas, L., Boulange-Lecomte, C., Rioult, D., Bultelle, F., Magal, P., et al. (2012). Different modalities of intercellular membrane exchanges mediate cellto-cell p-glycoprotein transfers in MCF-7 breast cancer cells. J. Biol. Chem. 287, 7374-7387. doi: 10.1074/jbc.M111.312157

Pasquier, J., Guerrouahen, B. S., Al Thawadi, H., Ghiabi, P., Maleki, M., AbuKaoud, N., et al. (2013). Preferential transfer of mitochondria from endothelial to cancer cells through tunneling nanotubes modulates chemoresistance. J. Transl. Med. 11:94. doi: 10.1186/1479-5876-11-94

Patel, R. S., Carter, G., El Bassit, G., Patel, A. A., Cooper, D. R., Murr, M., et al. (2016). Adipose-derived stem cells from lean and obese humans show depot specific differences in their stem cell markers, exosome contents and senescence: role of protein kinase $\mathrm{C}$ delta (PKCdelta) in adipose stem cell niche. Stem Cell Invest. 3:2. doi: 10.3978/j.issn.2306-9759.2016.01.02

Pegtel, D. M., Cosmopoulos, K., Thorley-Lawson, D. A., van Eijndhoven, M. A., Hopmans, E. S., Lindenberg, J. L., et al. (2010). Functional delivery of viral miRNAs via exosomes. Proc. Natl. Acad. Sci. U.S.A. 107, 6328-6333. doi: 10.1073/pnas.0914843107

Pegtel, D. M., van de Garde, M. D., and Middeldorp, J. M. (2011). Viral miRNAs exploiting the endosomal-exosomal pathway for intercellular cross-talk and immune evasion. Biochim. Biophys. Acta 1809, 715-721. doi: 10.1016/j.bbagrm.2011.08.002

Peralta, B., Gil-Carton, D., Castano-Diez, D., Bertin, A., Boulogne, C., Oksanen, H. M., et al. (2013). Mechanism of membranous tunnelling nanotube formation in viral genome delivery. PLoS Biol. 11:e1001667. doi: 10.1371/journal.pbio.1001667

Plotnikov, E. Y., Khryapenkova, T. G., Galkina, S. I., Sukhikh, G. T., and Zorov, D. B. (2010). Cytoplasm and organelle transfer between mesenchymal multipotent stromal cells and renal tubular cells in co-culture. Exp. Cell Res. 316, 2447-2455. doi: 10.1016/j.yexcr.2010.06.009

Plotnikov, E. Y., Khryapenkova, T. G., Vasileva, A. K., Marey, M. V., Galkina, S. I., Isaev, N. K., et al. (2008). Cell-to-cell cross-talk between mesenchymal stem cells and cardiomyocytes in co-culture. J. Cell Mol. Med. 12, 1622-1631. doi: 10.1111/j.1582-4934.2007.00205.x

Polak, R., de Rooij, B., Pieters, R., and den Boer, M. L. (2015). B-cell precursor acute lymphoblastic leukemia cells use tunneling nanotubes to orchestrate their microenvironment. Blood 126, 2404-2414. doi: 10.1182/blood-2015-03634238

Prattichizzo, F., Micolucci, L., Cricca, M., De Carolis, S., Mensà, E., Ceriello, A., et al. (in press). Exosome-based immunomodulation during aging: a nano-perspective on inflamm-aging. Mech. Aging Dev. doi: 10.1016/j.mad.2017.02.008

Raft, S., and Groves, A. K. (2015). Segregating neural and mechanosensory fates in the developing ear: patterning, signaling, and transcriptional control. Cell Tissue Res. 359, 315-332. doi: 10.1007/s00441-014-1917-6

Rainy, N., Chetrit, D., Rouger, V., Vernitsky, H., Rechavi, O., Marguet, D., et al. (2013). H-Ras transfers from B to T cells via tunneling nanotubes. Cell Death Dis. 4:e726. doi: 10.1038/cddis.2013.245

Rajendran, L., Honsho, M., Zahn, T. R., Keller, P., Geiger, K. D., Verkade, P., et al. (2006). Alzheimer's disease beta-amyloid peptides are released in association with exosomes. Proc. Natl. Acad. Sci. U.S.A. 103, 11172-11177. doi: 10.1073/pnas.0603838103

Ranzinger, J., Rustom, A., Abel, M., Leyh, J., Kihm, L., Witkowski, M., et al. (2011). Nanotube action between human mesothelial cells reveals novel aspects of inflammatory responses. PLoS ONE 6:e29537. doi: 10.1371/journal.pone.0029537

Ranzinger, J., Rustom, A., Heide, D., Morath, C., Schemmer, P., Nawroth, P. P., et al. (2014). The receptor for advanced glycation end-products (RAGE) plays a key role in the formation of nanotubes (NTs) between peritoneal mesothelial cells and in murine kidneys. Cell Tissue Res. 357, 667-679. doi: 10.1007/s00441-014-1904-y

Reichert, D., Scheinpflug, J., Karbanova, J., Freund, D., Bornhauser, M., and Corbeil, D. (2016). Tunneling nanotubes mediate the transfer of stem cell marker CD133 between hematopoietic progenitor cells. Exp. Hematol. 44, 1092.e2-1112.e2. doi: 10.1016/j.exphem.2016.07.006 
Robbins, P. D., and Morelli, A. E. (2014). Regulation of immune responses by extracellular vesicles. Nat. Rev. Immunol. 14, 195-208. doi: 10.1038/nri3622

Rustom, A. (2016). The missing link: does tunnelling nanotube-based supercellularity provide a new understanding of chronic and lifestyle diseases? Open Biol. 6:160057. doi: 10.1098/rsob.160057

Rustom, A., Bajohrs, M., Kaether, C., Keller, P., Toomre, D., Corbeil, D., et al. (2002). Selective delivery of secretory cargo in Golgi-derived carriers of nonepithelial cells. Traffic 3, 279-288. doi: 10.1034/j.1600-0854.2002.030405.x

Rustom, A., Saffrich, R., Markovic, I., Walther, P., and Gerdes, H. H. (2004). Nanotubular highways for intercellular organelle transport. Science 303, 1007-1010. doi: 10.1126/science.1093133

Sadeghipour, S., and Mathias, R. A. (2017). Herpesviruses hijack host exosomes for viral pathogenesis. Semin. Cell Dev. Biol. 67, 91-100. doi: 10.1016/j.semcdb.2017.03.005

Schiller, C., Diakopoulos, K. N., Rohwedder, I., Kremmer, E., von Toerne, C., Ueffing, M., et al. (2013a). LST1 promotes the assembly of a molecular machinery responsible for tunneling nanotube formation. J. Cell Sci. 126(Pt 3), 767-777. doi: $10.1242 /$ jcs. 114033

Schiller, C., Huber, J. E., Diakopoulos, K. N., and Weiss, E. H. (2013b). Tunneling nanotubes enable intercellular transfer of MHC class I molecules. Hum. Immunol. 74, 412-416. doi: 10.1016/j.humimm.2012.11.026

Schiller, P. C., D'Ippolito, G., Brambilla, R., Roos, B. A., and Howard, G. A. (2001). Inhibition of gap-junctional communication induces the transdifferentiation of osteoblasts to an adipocytic phenotype in vitro. J. Biol. Chem. 276, 14133-14138. doi: 10.1074/jbc.M011055200

Schwab, A., Meyering, S. S., Lepene, B., Iordanskiy, S., van Hoek, M. L., Hakami, R. M., et al. (2015). Extracellular vesicles from infected cells: potential for direct pathogenesis. Front. Microbiol. 6:1132. doi: 10.3389/fmicb.2015.01132

Seyed-Razavi, Y., Hickey, M. J., Kuffova, L., McMenamin, P. G., and Chinnery, H. R. (2013). Membrane nanotubes in myeloid cells in the adult mouse cornea represent a novel mode of immune cell interaction. Immunol. Cell Biol. Immunol. 91, 89-95. doi: 10.1038/icb.2012.52

Sherer, N. M., and Mothes, W. (2008). Cytonemes and tunneling nanotubules in cell-cell communication and viral pathogenesis. Trends Cell Biol. 18, 414-420. doi: 10.1016/j.tcb.2008.07.003

Silva, A. M., Teixeira, J. H., Almeida, M. I., Goncalves, R. M., Barbosa, M. A., and Santos, S. G. (2017). Extracellular vesicles: immunomodulatory messengers in the context of tissue repair/regeneration. Eur. J. Pharm. Sci. 98, 86-95. doi: 10.1016/j.ejps.2016.09.017

Smith, I. F., Shuai, J., and Parker, I. (2011). Active generation and propagation of $\mathrm{Ca} 2+$ signals within tunneling membrane nanotubes. Biophys. J. 100, L37-L39. doi: 10.1016/j.bpj.2011.03.007

Sowinski, S., Alakoskela, J. M., Jolly, C., and Davis, D. M. (2011). Optimized methods for imaging membrane nanotubes between $\mathrm{T}$ cells and trafficking of HIV-1. Methods 53, 27-33. doi: 10.1016/j.ymeth.2010.04.002

Sowinski, S., Jolly, C., Berninghausen, O., Purbhoo, M. A., Chauveau, A., Kohler, $\mathrm{K}$., et al. (2008). Membrane nanotubes physically connect $\mathrm{T}$ cells over long distances presenting a novel route for HIV-1 transmission. Nat. Cell Biol. 10, 211-219. doi: $10.1038 / \mathrm{ncb} 1682$

Spees, J. L., Olson, S. D., Whitney, M. J., and Prockop, D. J. (2006). Mitochondrial transfer between cells can rescue aerobic respiration. Proc. Natl. Acad. Sci. U.S.A. 103, 1283-1288. doi: 10.1073/pnas.0510511103

Sun, X., Su, J., Bao, J., Peng, T., Zhang, L., Zhang, Y., et al. (2012). Cytokine combination therapy prediction for bone remodeling in tissue engineering based on the intracellular signaling pathway. Biomaterials 33, 8265-8276. doi: 10.1016/j.biomaterials.2012.07.041

Takahashi, A., Okada, R., Nagao, K., Kawamata, Y., Hanyu, A., Yoshimoto, S., et al. (2017). Exosomes maintain cellular homeostasis by excreting harmful DNA from cells. Nat. Commun. 8:15287. doi: 10.1038/ncomms15287

Tardivel, M., Begard, S., Bousset, L., Dujardin, S., Coens, A., Melki, R., et al. (2016). Tunneling nanotube (TNT)-mediated neuron-to neuron transfer of pathological Tau protein assemblies. Acta Neuropathol. Commun. 4, 117. doi: 10.1186/s40478-016-0386-4

Thayanithy, V., Babatunde, V., Dickson, E. L., Wong, P., Oh, S., Ke, X., et al. (2014a). Tumor exosomes induce tunneling nanotubes in lipid raftenriched regions of human mesothelioma cells. Exp. Cell Res. 323, 178-188. doi: 10.1016/j.yexcr.2014.01.014
Thayanithy, V., Dickson, E. L., Steer, C., Subramanian, S., and Lou, E. (2014b). Tumor-stromal cross talk: direct cell-to-cell transfer of oncogenic microRNAs via tunneling nanotubes. Transl. Res. 164, 359-365. doi: 10.1016/j.trsl.2014.05.011

Torralba, D., Baixauli, F., and Sanchez-Madrid, F. (2016). Mitochondria know no boundaries: mechanisms and functions of intercellular mitochondrial transfer. Front. Cell Dev. Biol. 4:107. doi: 10.3389/fcell.2016. 00107

Tsuji, K., and Kitamura, S. (2015). Trophic factors from tissue stem cells for renal regeneration. Stem Cells Int. 2015:537204. doi: 10.1155/2015/537204

Twiss, J. L., and Fainzilber, M. (2009). Ribosomes in axons-scrounging from the neighbors? Trends Cell Biol. 19, 236-243. doi: 10.1016/j.tcb.2009.02.007

Urbanelli, L., Buratta, S., Sagini, K., Tancini, B., and Emiliani, C. (2016). Extracellular vesicles as new players in cellular senescence. Int. J. Mol. Sci. 17:1408. doi: 10.3390/ijms17091408

Valente, S., Rossi, R., Resta, L., and Pasquinelli, G. (2015). Exploring the human mesenchymal stem cell tubule communication network through electron microscopy. Ultrastruct. Pathol. 39, 88-94. doi: 10.3109/01913123.2014.960545

Vallabhaneni, K. C., Haller, H., and Dumler, I. (2012). Vascular smooth muscle cells initiate proliferation of mesenchymal stem cells by mitochondrial transfer via tunneling nanotubes. Stem Cells Dev. 21, 3104-3113. doi: $10.1089 / \mathrm{scd} .2011 .0691$

Vella, L. J., Hill, A. F., and Cheng, L. (2016). Focus on extracellular vesicles: exosomes and their role in protein trafficking and biomarker potential in Alzheimer's and Parkinson's Disease. Int. J. Mol. Sci. 17:173. doi: 10.3390/ijms17020173

Victoria, G. S., Arkhipenko, A., Zhu, S., Syan, S., and Zurzolo, C. (2016). Astrocyteto-neuron intercellular prion transfer is mediated by cell-cell contact. Sci. Rep. 6:20762. doi: 10.1038/srep20762

Wang, X., and Gerdes, H. H. (2012). Long-distance electrical coupling via tunneling nanotubes. Biochim. Biophys. Acta 1818, 2082-2086. doi: 10.1016/j.bbamem.2011.09.002

Wang, X., and Gerdes, H. H. (2015). Transfer of mitochondria via tunneling nanotubes rescues apoptotic PC12 cells. Cell Death Differ. 22, 1181-1191. doi: 10.1038/cdd.2014.211

Wang, X., Veruki, M. L., Bukoreshtliev, N. V., Hartveit, E., and Gerdes, H. H. (2010). Animal cells connected by nanotubes can be electrically coupled through interposed gap-junction channels. Proc. Natl. Acad. Sci. U.S.A. 107, 17194-17199. doi: 10.1073/pnas.1006785107

Wang, X., Yu, X., Xie, C., Tan, Z., Tian, Q., Zhu, D., et al. (2016). Rescue of brain function using tunneling nanotubes between neural stem cells and brain microvascular endothelial cells. Mol. Neurobiol. 53, 2480-2488. doi: $10.1007 / \mathrm{s} 12035-015-9225-\mathrm{z}$

Ware, M. J., Tinger, S., Colbert, K. L., Corr, S. J., Rees, P., Koshkina, N., et al. (2015). Radiofrequency treatment alters cancer cell phenotype. Sci. Rep. 5:12083. doi: $10.1038 /$ srep 12083

Watkins, S. C., and Salter, R. D. (2005). Functional connectivity between immune cells mediated by tunneling nanotubules. Immunity 23, 309-318. doi: 10.1016/j.immuni.2005.08.009

Webber, J. P., Spary, L. K., Sanders, A. J., Chowdhury, R., Jiang, W. G., Steadman, R., et al. (2015). Differentiation of tumour-promoting stromal myofibroblasts by cancer exosomes. Oncogene 34, 290-302. doi: 10.1038/onc. 2013.560

Weber, G. F., Bjerke, M. A., and DeSimone, D. W. (2011). Integrins and cadherins join forces to form adhesive networks. J. Cell Sci. 124(Pt 8), 1183-1193. doi: $10.1242 /$ jcs. 064618

Weng, Z., Zhang, B., Tsilioni, I., and Theoharides, T. C. (2016). Nanotube Formation: a Rapid Form of "Alarm Signaling?" Clin. Ther. 38, 1066-1072. doi: 10.1016/j.clinthera.2016.02.030

Yang, H., Borg, T. K., Ma, Z., Xu, M., Wetzel, G., Saraf, L. V., et al. (2016). Biochip-based study of unidirectional mitochondrial transfer from stem cells to myocytes via tunneling nanotubes. Biofabrication 8:015012. doi: 10.1088/1758-5090/8/1/015012

Yasuda, K., Khandare, A., Burianovskyy, L., Maruyama, S., Zhang, F., Nasjletti, A., et al. (2011). Tunneling nanotubes mediate rescue of prematurely senescent endothelial cells by endothelial progenitors: exchange of lysosomal pool. Aging 3, 597-608. doi: 10.18632/aging.100341 
Zaccard, C. R., Rinaldo, C. R., and Mailliard, R. B. (2016). Linked in: immunologic membrane nanotube networks. J. Leukoc. Biol. 100, 81-94. doi: 10.1189/jlb.4VMR0915-395R

Zani, B. G., and Edelman, E. R. (2010). Cellular bridges: routes for intercellular communication and cell migration. Commun. Integr. Biol. 3, 215-220. doi: $10.4161 /$ cib.3.3.11659

Zhang, L., and Zhang, Y. (2015). Tunneling nanotubes between rat primary astrocytes and C6 glioma cells alter proliferation potential of glioma cells. Neurosci. Bull. 31, 371-378. doi: 10.1007/s12264-014-1522-4

Zhang, N., Bing, T., Shen, L., Song, R., Wang, L., Liu, X., et al. (2016). Intercellular connections related to cell-cell crosstalk specifically recognized by an Aptamer. Angew. Chem. Int. Ed. Engl. 55, 3914-3918. doi: 10.1002/anie.2015 10786

Zhang, Y. (2011). Tunneling-nanotube: a new way of cell-cell communication. Commun. Integr. Biol. 4, 324-325. doi: 10.4161/cib.4.3.14855

Zhang, Y., Yu, Z., Jiang, D., Liang, X., Liao, S., Zhang, Z., et al. (2016). iPSCMSCs with high intrinsic MIRO1 and sensitivity to TNF- $\alpha$ yield efficacious mitochondrial transfer to rescue anthracycline-induced cardiomyopathy. Stem Cell Rep. 7, 749-763. doi: 10.1016/j.stemcr.2016.08.009

Zhao, Y., and Guo, W. (2009). Sec-ure nanotubes with RalA and exocyst. Nat. Cell Biol. 11, 1396-1397. doi: 10.1038/ncb1209-1396
Zhu, H., Xue, C., Xu, X., Guo, Y., Li, X., Lu, J., et al. (2016). Rab8a/Rab11a regulate intercellular communications between neural cells via tunneling nanotubes. Cell Death Dis. 7:e2523. doi: 10.1038/cddis.2016.441

Zhu, S., Victoria, G. S., Marzo, L., Ghosh, R., and Zurzolo, C. (2015). Prion aggregates transfer through tunneling nanotubes in endocytic vesicles. Prion 9, 125-135. doi: 10.1080/19336896.2015.1025189

Zitvogel, L., Regnault, A., Lozier, A., Wolfers, J., Flament, C., Tenza, D., et al. (1998). Eradication of established murine tumors using a novel cell-free vaccine: dendritic cell-derived exosomes. Nat. Med. 4, 594-600. doi: $10.1038 / \mathrm{nm} 0598-594$

Conflict of Interest Statement: The authors declare that the research was conducted in the absence of any commercial or financial relationships that could be construed as a potential conflict of interest.

Copyright (c) 2017 Nawaz and Fatima. This is an open-access article distributed under the terms of the Creative Commons Attribution License (CC BY). The use, distribution or reproduction in other forums is permitted, provided the original author(s) or licensor are credited and that the original publication in this journal is cited, in accordance with accepted academic practice. No use, distribution or reproduction is permitted which does not comply with these terms. 